\title{
FEDERAL TAX LIENS AND ASSIGNEES OF ACCOUNTS RECEIVABLE: PRIORITY WITHOUT REASON
}

The economic facts of life too often leave a man with more debts than credits. If creditors display a persistency to collect and the debtor's assets are insufficient to go around, judicial action is likely. The legal problem of distributing not enough among too many, a task which will almost necessarily result in some dissatisfaction, can have disturbing aspects when one of the competing claimants is the federal tax collector. In this distribution recent cases have accorded a position of virtual omnipotence to federal tax liens. 1

Of particular concern is one type of secured creditor-a man who loans money or gives value and contracts for an assignment of accounts receivable as security for the debtor's note. This is a contractual security interest which may be called a lien. ${ }^{2}$ Because his claim is against specific property, the lienor has a stronger interest in those accounts than do any of the debtor's general creditors. Furthermore he has contracted for his security interest. Therefore the transaction may be analyzed as giving the assignee a limited property right in, distinct and superior to a general claim against, those specific accounts. In general, priority between two creditors holding valid liens on the same property depends on the priority in time of attachment of the respective interest. 3 However, a federal tax lien is normally given special treatment. A lienor's

1 United States v. R.F. Ball Constr. Co., 355 U.S. 587 (1958); United States v. White Bear Brewing Co., 350 U.S. 1010 (1956); United States v. Scovil, 348 U.S. 218 (1955); United States v. Liverpool \& London \& Globe Ins. Co., 348 U.S. 215 (1955); United States v. Acri, 348 U.S. 211 (1955); United States v. City of New Britain, 347 U.S. 81 (1954); United States v. Gilbert Associates, 345 U.S. 361 (1953); United States v. Security Trust \& Sav. Bank, 340 U.S. 47 (1950); United States v. Chapman, 281 F.2d 862 (10th Cir. 1960); United States v. King's County Iron Works, Inc., 224 F.2d 232 (2d Cir. 1955); United States v. Wilson, 195 F. Supp. 332 (D.N.J. 1961); Arthur Co.v. Chicago Paint, Inc., 175 F. Supp. 50 (D. Minn. 1959); First State Bank v. United States, 166 F. Supp. 204 (D. Minn. 1958). Contra, Hoare v. United States, 294 F.2d 823 (9th Cir. 1961); Gauvey v. United States, 219 F.2d 42 (8th Cir. 1961); Marteney v. United States, 245 F.2d 135 (10th Cir. 1957); National Ref. Co. v. United States, 160 F.2d 951 (8th Cir. 1947); Elliott v. Sioux Oil Co., 191 F.Supp. 847 (D. Wyo. 1960); United States v. Boston \& Berlin Trans Co., 188 F. Supp. 304 (D.N.H. 1960); Aetna Cas. \& Sur. Co. v. Port of New Yórk Auth., 182 F. Supp. 671 (S.D.N.Y. 1960); Evans v. Stewart, 245 la. 1268, 66 N.W.2d 442 (1954).

2 "The very concept of a lien involves contingencies either precedent or subsequent, or both, which puts it in a position intermediate between a mere general unsecured claim, on the one hand, and a complete and unqualified property right, on the other hand." MacLachlan, Current Developments Relating to Federal Liens and Practice, 66 Coм. L.J. 267 (1961).

${ }^{3}$ Michigan v. United States, 317 U.S. 338 (1943); United States v. Beaver, 252 F.2d 486 (3d Cir. 1958); Ersa, Inc. v. Dudley, 234 F.2d 178 (3d Cir. 1956); United States v. Atlantic Municipal Corp., 212 F.2d 709 (5th Cir. 1954); United States v. Albert Holman Lumber Co., 208 F.2d 113 (5th Cir. 1953); cf. United States v. Toys of the World Club, Inc., 288 F.2d 89, 92 (2d Cir. 1961); Bank of Nevada v. United States, 251 F.2d 820, 825 (9th Cir. 1957); United States v. Saidman, 231 F.2d 503, 511 (D.C. Cir. 1956); United States v. White Bear Brewing Co., 227 F.2d 359 (7th Cir. 1955), rev'd, 350 U.S. 1010 (1956); United States v. Liverpool \& London \& Globe Ins. Co., 209 F.2d 684, 689 (5th Cir. 1953), rev'd, 
chance of recovering on his security diminishes greatly should the debtor default on his taxes, regardless of the time priority.

Federal tax lien priority is a phenomenon of recent origin. It is not based on any sovereign power. 4 Nor has Congress been responsible for legislating tax liens into a superior position, although the statutory delineation of tax claims as liens did establish a priority over general creditors. 5 Rather, one must look to the specific and perfected lien doctrine, which had been evolving for over twenty years 6 before the Supreme Court first passed on the subject in 1950. In United States $v$. Security Trust, ${ }^{7}$ an attachment lien, which had not been reduced to judgment, was considered "inchoate,"8 and thus lost priority to a subsequent tax lien. First utilized against state statutory liens in the thirties and forties, this test of specificity and perfection virtually emasculated the prevailing priority rule: first in time, first in right. 9 Specificity meant that the

348 U.S. 215 (1955); see United States v. City of New Britain, 347 U.S. 81, 85 (1954): "We believe that priority of these statutory liens is determined by another principle of law, namely, 'the first in time is the first in right.' As stated by Chief Justice Marshall in Rankin v. Scott, ... The principle is believed to be universal, that a prior lien gives claim, which is entitled to prior satisfaction, out of the subject it binds. ... This principle is widely accepted and applied, in the absence of legislation to the contrary."

4 In re Meyer's Estate, 159 Pa. Super. 296, 48 A.2d 210 (1946); See Kennedy, The Relative Priority of the Federal Government: The Pernicious Career of the Inchoate and General Lien, 63 YALE L.J. 905 n.1 (1954).

5 INT. REv. CODE OF 1954, § 6321. "If any person ... refuses to pay [taxes] . . . after demand, the amount ... shall be a lien in favor of the United States ... "The lien would attach following the assessment of unpaid taxes. Although superior to general claims by virtue of being a lien, the government's interest enjoyed no express priority over other lien holders.

6 The source of the government's claim to priority, where the debtor's property is insufficient to satisfy all creditors, is found in a 1929 decision which initiated the doctrine of the inchoate and general lien. The doctrine reduced a lien's status to that of a mere general claim if certain specificity and perfection requirements were not met. Once reduced to this level, a federal statute, REV. STAT. \$ 3466 (1875), 31 U.S.C. \$191 (1958), was introduced which allowed government debts first priority over other general claims in cases of insolvency. Thus liens first in time could be defeated by subsequent government tax claims. Actually all the Supreme Court did in the 1929 decision, Spokane County v. United States, 279 U.S. 80, 94 (1929), was to affirm a Washington Supreme Court holding that competing state and county tax liens were not specific because, in the words of the concurring state judge: "[n]either ... the state . . . nor Spokane County ... has ever, by the prescribed statutory procedure, perfected its inchoate tax lien right against any of the property of which the funds here in question are the proceeds. I therefore view these respective tax debts wholly apart from any supporting lien right." Exchange Nat'l Bank v. United States, 147 Wash. 176, 187, 265 Pac. 722,726 (1928). Thus inaugurated, the "general and inchoate lien" theory (or "specific and perfected lien" doctrine) was developed in the main against state statutory liens, and a federal law of specificity and perfection independent of state concepts gradually evolved.

7340 U.S. 47 (1950).

8 "Inchoate" referring to something incomplete is synonymous with "unperfected." See Note, 43 MinN. L. REV. 755, 756 n.7 (1959).

9 See note 3 supra. Every case cited in notes 12 and 13 infra violates the "first in time" principle by giving later federal tax liens priority, although the government has maintained that "first in time" was still effective under the guise of first in time with a specific and perfected lien. 
lienor must be identified, the amount of the lien must be certain, and property subject to the lien had to be defined.10 Perfection was a broad but unclear term that encompassed requirements of notice, and enforcing one's lien, sometimes to the extent of obtaining title and possession. ${ }^{11}$ Although Security Trust turned on the lienor's failure to meet state perfection standards, it acknowledged the pre-eminence of federal perfection law. Thus interests sanctioned as perfected under state requirements could be defeated easily under the more stringent specificity and perfection requirements of the federal courts. ${ }^{12}$ In tax

10 United States v. City of New Britain, 347 U.S. 81, 84 (1954); Illinois ex rel. Gordon v. Campbell, 329 U.S. 362, 375 (1946): "The long established rule requires that the lien must be definite .... in at least three respects as of the crucial time. These are: (1) the identity of the lienor, United States v. Knott, 298 U.S. 544, 549-551; (2) the amount of the lien, United States v. Waddill Co., 323 U.S. at 357-358; and (3) the property to which it attaches, United States v. Waddill Co., supra; United States v. Texas, 314 U.S. 480 (1941); New York y. Maclay, 288 U.S. 290 (1933)." See Note, 43 MiNN. L. Rev., supra note 8, at 756, n.7.

11 United States v. Gilbert Associates, 345 U.S. 361, 366 (1953); United States v. Texas, 314 U.S. 480, 488 (1941) (the state lien was "inchoate and general" because the lien "did not of its own force divest the taxpayer of either title or possession"). New York v. Maclay, 288 U.S. 290, 293-94 (1933); See United States v. White Bear Brewing Co., 350 U.S. 1010 (1956); Note, 43 MinN. L. ReV., supra note 8, at 756, n.7.

${ }^{12}$ For "stringent application," see, e.g., United States v. Gilbert Associates, 345 U.S. 361 (1953). A municipal ad valorem property tax lien, which had been foreclosed by sale of the property before the section 3466 priority arose, was denied priority because the lien had not been reduced to possession. Illinois ex rel. Gordon v. Campbell, 329 U.S. 362 (1946) (state lien for unemployment contributions was filed and suit was brought to enforce it). A subsequent section 3466 lien was held superior because the property subject to the lien was indefinite since the taxpayer had not filed a schedule of all his personal property. See United States v. Waddill, Holland \& Flinn, Inc., 323 U.S. 353 (1945), where a statutory landlord's lien was not specific and perfected because (1) there was a contingency in not knowing (on the day the federal claim attached) whether the landlord would insist upon his lien rights; (2) the amount of the lien was indefinite ("The landlord may have been mistaken as to the rental rate or as to payments previously made..." id. at 357); and (3) the landlord had neither title nor possession of the property. This case also inaugurated the "general and inchoate lien" doctrine as a federal question. "[I]t is a matter of federal law as to whether a lien created by state statute is sufficiently specific and perfected to raise questions as to the applicability of the priority given the claims of the United States by an act of Congress." Id. at 356-57. In United States v. Texas, 314 U.S. 480 (1941), a state lien for gasoline taxes yielded priority to a subsequent federal claim because (1) the property subject to the lien was indefinite because of vague statutory language providing that the state lien attached to property which was "devoted to or used in his business as a distributor." Id. at 487. (2) The amount was uncertain because the amount of taxes due was left to be determined by the state courts. In NewYork v. Maclay, 288 U.S. 290 (1933), a state lien for franchise taxes was inchoate because the taxes had not been assessed or liquidated until after the federal priority attached. In United States v. Saidman, 231 F.2d 503 (D.C. Cir. 1956), a landlord failed to perfect his statutory rent lien by acquiring title or taking possession. In United States v. Division of Labor Law Enforcement, 201 F.2d 857 (9th Cir. 1953), wage lien claimants were held to have unperfected liens against an insolvent corporation which had assigned funds to a third person for the benefit of creditors. Cf. Massachusetts v. United States, 333 U.S. 611 (1948). It should be noted that in the earlier cases the Government won its priority in the Supreme Court but not in the lower federal courts. This general disapproval of the choate lien doctrine in the lower courts was reflected by their continued reluctance to treat federal claims, particularly federal tax liens, any differently from other liens. For a list of some thirty cases in which lower courts denied the supremacy of the section 3670 tax lien over antedating rival liens without considering the general and inchoate doctrine, see Kennedy, supra note 5, at 924 n.115. 
lien cases subsequent to Security Trust the doctrine was argued so convincingly that in only one instance did the Supreme Court find a competing lien that qualified as "specific and perfected."13

Recently, attention has shifted to the problem of the priority of federal tax liens vis-a-vis security interests. Certain enumerated security interests were apparently protected by Section 6323 of the Internal Revenue Code, which provided that tax liens would not be valid against any "mortgagee, purchaser, pledgee, or judgment creditor until notice has been filed."14 This language has been interpreted to mean that a United States tax lien is automatically inferior to the contractual interests of mortgagees or pledgees acquired prior to the notice filing. 15 However, extension of the "general and inchoate lien" theory against even these special consensual interests became a real possibility in 1958 , as the commercial world watched with interest and apprehension when United States v. R. V. Ball Constr. Co.16 came before the Supreme Court. A bonding company has secured its possibile liability on a performance bond

13 United States v. City of New Britain, 347 U.S. 81 (1954), where the rule of "first in time, first in right" was followed as to certain city tax and water-rent liens which were adjudged to have attached to specific property and thus to have become choate prior to the federal assessment. One interesting incongruity is that the liens there were not accompanied by possession or title, the lack of which had been fatal to one town's claim to a specific and perfected lien in United States v. Gilbert Associates, Inc., 345 U.S. 361 (1953).

On the other hand, the tax collector's victory slate is quite impressive. United States v. White Bear Brewing Co., 350 U.S. 1010 (1956); United States v. Colotta, 350 U.S. 808 (1955); United States v. Acri, 348 U.S. 211 (1955); United States v. Liverpool \& London \& Globe Ins. Co., 348 U.S. 215 (1955); United States v. Scovil, 348 U.S. 218 (1955); United States v. Security Trust \& Sav. Bank, 340 U.S. 47 (1950). However, assimilation of the specific-choate theory is discernable in some lower court decisions. United States v. Bond, 279 F.2d 837 (4th Cir. 1960) (payments of estate taxes and attorney's fees were ruled inchoate despite their purpose of protecting a perfected mortgage because they were undetermined until after the federal lien attached). Massachusetts Bonding \& Ins. Co. v. New York, 259 F.2d 33 (2d Cir. 1958) (a state tax lien was not sufficiently perfected to defeat a subsequent federal tax lien because the state had failed to issue warrants to enforce its statutory lien.) Ersa, Inc. v. Dudley, 234 F.2d 178 (3d Cir. 1956) (under Pennsylvania law the mere filing of a lien for unpaid unemployment contributions and its reduction to judgment does not create a perfected lien upon the delinquent taxpayer's personal property). Narragansett Bay Gardens, Inc. v. Grant Constr. Co., 176 F. Supp. 451 (D.R.I. 1959) (a creditor's attachment liens were ruled inchoate in the absence of a final judgment). United States y. Bleasby, $153 \mathrm{~F}$. Supp. 724 (D.N.J. 1957) (a fund seized by county officials pursuant to state law did not give the state a choate lien where the federal tax lien intervened before a judgment of forfeiture was had). Mason City \& Clear Lake R. R. v.Imperial Seed Co., 152 F. Supp. 145 (N.D. Iowa 1957) (a landlord's statutory contract liens on his lessee's property were held inferior to a subsequent tax claim because of his failure to record). $C f$. Kel Weatherstrip Co. v. Rankin, 124 F. Supp. 555 (D. Alaska 1954) (a contractor's mechanic's lien was unperfected because unfiled, although work had already begun).

However, many of the lower courts managed to avoid the implication of United States v. Security Bank, 340 U.S. 47 (1950), by finding perfection standards satisfied by liens competing with the federal tax claims. Or they characterized the state-created interests in such a way as to bring the lienors within the protection of section 6323 . See text accompanying note 16 infra. For a listing of these cases, see Kennedy, supra note 5, at 925-26, nn. 118-20.

14 INT. REv. CODE of 1954, § 6323(a).

15 See United States v. Sampsell, 153 F.2d 731, 734 (9th Cir. 1946).

16355 U.S. 587 (1958). 
along with other potential debts by accepting an assignment of a specific account which was subsequently challenged by a federal tax lien. The lower court awarded the surety preference, holding him to be a mortgagee under section 6323.17 The Supreme Court reversed five to four and held per curiam: "The instrument involved being inchoate and unperfected, the provisions of $\S 6323$ do not apply."18 The implications and consequences of this decision for security interests, particularly fcr assignments of accounts receivable, delineate the focus of this comment. 19

Accounts receivable financing was little known as a security device when section 6323 was enacted in 1913. Even in the 1930's when the practicality of using accounts receivable financing and thus maximizing business assets gained recognition, the opprobrium of "last ditch financing" attended its early years. The inherent secrecy in assigning accounts was considered peculiarly susceptible to the defrauding of other creditors. 20 Publicizing accounts receivable financing was avoided because the popular suspicion and distrust surrounding this method could easily jeopardize credit standings. However, rapid growth has brought both an acceptance of and a respectibility to accounts receivable financing-now a thirty billion dollar a year business. ${ }^{21}$ Indeed, the liquidity of accounts receivable recommends them as a sound security device in that they are free of the hazards of merchandizing. 22

17 R. F. Ball Constr. Co. v. Jacobs, 140 F.Supp. 60 (W. D. Tex.), aff'd mem., 239 F.2d 384 (5th Cir. 1956).

18 United States v. R. F. Ball Constr. Co., 355 U.S. 587 (1958).

19 One should be aware of another line of argument which may be used to defeat the federal tax lien. Competing assignees may establish that the property on which the government seeks to levy is not the property of the taxpayer. For example, a manufacturer who borrowed money and assigned as security the proceeds on a then executory contract was held to have no right to those proceeds to which a federal tax lien could attach. In re Halprin, 280 F.2d 407 (3d Cir. 1960). In June, 1960, the Supreme Court issued companion decisions holding that in the application of the federal tax lien statute, state law controls in determining the nature of the legal interest held by the delinquent taxpayer in the property covered by the federal tax lien. The Court emphasized that the tax lien statute, section 6321, created no property rights, but merely attached federally defined consequences to rights created under state law. United States v. Durham Lumber Co., 363 U.S. 522 (1960); Aquilino v. United States, 363 U.S. 509 (1960). In these cases the Court found that contractors who defaulted on their taxes had no enforceable right to contract proceeds to which tax liens could attach to the extent of outstanding claims of unpaid subcontractors. Similarly, a client who assigns part of his cause of action to his attomey, thereby divesting himself under state law of any property in that portion, has "no property" in that portion to which a subsequent federal tax lien can attach. In re City of New York, 5 N.Y.2d 300, 184 N.Y.S.2d 585, 157 N.E. 2d 587 (1959). For a comprehensive analysis of this "no property" doctrine, see Note, The Federal Tax Lien, 36 N.Y.U.L. REv. 1316 (1961). The author of this note states that "cases in at least seventeen states indicate that the assignor by the assignment has divested himself of any property right in the money due or to become due, at least to the extent of sums advanced and secured by the assignment at the time in question." Id. at 1331 .

20 See Note, 28 U. CHI. L. REv. 130, 132 n.8 (1960).

21 Id. at 131 n.6. At the end of 1945, the total outstanding consumer installment credit held by financial institutions was $\$ 1,776,000,000$; at the end of 1959 , the amount was $\$ 34,003,000,000$. Federal Reserve Bulletin, March, 1960. 1952.

22 See Kripke, Address Before the Bar Association of the City of New York, April 14, 
In considering the relationship of accounts receivable financing to section 6323 two major questions, which at times seem almost to be one, are presented. Can an assignment of accounts receivable be brought under the exception statute as a mortgage, pledge, or purchase? Once within these terms, to what extent must such an assignment be perfected in order to meet the choate lien standard, as this test is applied to section 6323 interests ?23 The questions coalesce when an interest is said not to be within the statutory terms "because" it is unperfected.

A broad preliminary argument could be made against the inclusion of accounts receivable assignments within section 6323 on the basis of statutory intent. Presumably, the evil aimed at was the secrecy of government liens. The interests protected were apparently chosen on the basis that they were commercial devices which were generally recognized to be accompanied by sufficient notoriety. Accounts receivable assignments, although a security interest like a mortgage or pledge, in many instances lack the publicity of recording or possession; therefore it may be argued that they do not come within the congressional intent. A constructive intent argument, however, is generally considered speculative and has been largely ignored by the courts dealing with the problem.

The first question of whether an assignment of accounts receivable can be considered a mortgage, pledge, or purchase is determined by a combination of state and federal law. "Although the relation of a state-created right to federal laws for the collection of federal credits is a federal question, the State's classification of state-created rights must be given weight." 24 The Internal Revenue Regulations state that:

The determination whether a person is a mortgagee, pledgee, purchaser, or judgment creditor, entitled to the protection of section 6323(a) shall be made by reference to the realities and the facts in a given case rather than to the technical form or terminology used to designate such person. Thus a person who is in fact and in law a mortgagee, pledgee, or purchaser will be entitled as such to the protection of $\S 6323$ (a) even though such person is

23 At least six cases suggest that the choate lien doctrine "can" be applied to section 6323 interests. United States v. R. F. Ball Constr. Co., 355 U.S. 587 (1958); United States v. Crest Fin. Co., Inc., 291 F.2d 1 (7th Cir.), cert. granted, vacated and remanded 368 U.S. 349 (1961), opinion on remand, (7th Cir. May 3, 1962); United States v. Chapman, 281 F.2d 862 (10th Cir. 1960); Randall v. Colby, 190 F. Supp. 319 (N.D. Iowa 1961); Arthur Co. v. Chicago Paints, Inc., 175 F. Supp. 50 (D. Minn. 1959); First State Bank v. United States, 166 F. Supp. 204 (D. Minn. 1958). See Note, 43 MINN. L. REv. 755 (1959).

24 United States v. Security Trust \& Sav. Bank, 340 U.S. 47, $49-50$ (1950). See United States v. R. F. Ball Constr. Co., 355 U.S. 587, 593 (1958) (dissenting opinion): "Here, the State's determination that such assignnents are mortgages in legal effect, and its classification of them accordingly, is not met by anything of countervailing weight." Fidelity \& Deposit Co. v. New York City Housing Authority, 241 F.2d 142, 144 (2d Cir. 1957): "The statute was fashioned to require the courts to determine for federal purposes whether those state-created interests are 'property' or 'rights to property.' That classification of interests is a federal question; the existence of the interests to be federally classified, however, is solely a question of state law." 
otherwise designated under the laws of a State, such as the Uniform Commercial Code.25

The Regulations specifically define a "purchaser" as a person who, for a valuable present consideration, acquires property or an interest in property. ${ }^{26}$ Under this definition a direct assignment of an account receivable in return for present new value would probably be considered a "purchase." 27 The Supreme Court, however, has considered the subject: "A purchaser within the meaning of $\S 6323$ usually means one who acquires title for a valuable consideration in the manner of vendor and vendee." 28 This definition creates difficulties where the assignment is to serve only a security function. Must a security transaction be cast in the form of a sale in order to be protected by section 6323? Practically there may be little difference between a situation where a creditor accepts the assignment of accounts as direct "consideration" for a monetary advance, and an instance where the same creditor accepts the same assignment of the same accounts as "security" for a loan. Presumably money is received in both instances. Common banking practice supports this "purchase" theory of accounts receivable financing. Despite the "security interest" label attached to such assignments, a creditor bank will generally receive "payment in kind" in the form of the accounts receivable payments which have been made to the debtor by the consumer purchaser.29 Thus, in reality, the assigned accounts are the actual consideration for the creditor's loan. It may be argued that despite the term "security interest" and regardless of the assignee's lack of "title," the bargained-for consideration is the account. ${ }^{30}$ Therefore the average security transaction involving accounts receiv-

${ }_{25}$ Reg. Sec. 301.6323-(2)ii; Plumb, Federal Tax Collection and Lien Problems, 13 TAX L. REv. 459, 492-93 (1958): "The label applied by state law is not controlling, and one may be a 'mortgagee' or 'pledgee' for purposes of these rules even though he is called a beneficiary of a deed of trust, factor, entruster, or holder of a security interest. An assignee of wages or of an account receivable to secure a debt fits one or the other of such categories." 1947).

${ }^{26}$ Reg. Sec. 301.6323-(2)i(a); National Ref. Co. v. United States, 160 F.2d 951 (8th Cir.

27 See Wadley Nurseries, Inc. v. Matac Constr. Corp., 55-2 U.S.T.C. 55, 805 (1955) (an agreement not to sue on a mechanic's lien in return for the assignment was considered a present consideration and therefore new value). Indeed, in two cases the relinquishment and extension of time on pre-existing debts was found to constitute consideration sufficient to make assignees "purchasers" within the statute. Marteney v. United States, 245 F.2d 135 (10th Cir. 1957); National Ref. Co. v. United States, 160 F.2d 951 (8th Cir. 1947). Differences between relinquishing a debt claim in return for an assignment and receiving that assignment as security for the antecedent debt seem slight, except for a variation in the words as to presentness of value. Although the nature of the interests transferred seems extraordinarily similar, the former assignee may more easily be considered a purchaser because of the manner of the transaction.

28 United States v. Scovil, 348 U.S. 218, 221 (1955).

29 This information was provided by the commercial departments of two Chicago banks, the Harris Trust and the First National.

${ }^{30}$ Assignments as security interests have been referred to as "qualified interests," United States v. Chapman, 281 F.2d 862, 868 (10th Cir. 1960), a term which seemingly connotes 
able may be viewed as a sale of money now for money later. This situation is distinguishable from the situation where loans are secured by chattels or land or documents, since in the latter situation the creditor's expected consideration is quite distinct from his security interest. It should be noted that recent case law supports the distinction between a lienor holding an assignment of accounts as security and a purchaser as defined in terms of vendee-vendor. ${ }^{31}$ However, the facts and realities of accounts receivable financing, as exemplified by customary banking practice, make it reasonable to label an assignee of this type of security interest a purchaser under section 6323.32 Moreover the accepted concept of a purchaser as including mortgagees, pledgees, and all who acquire interests in property through voluntary transactions is followed by the Uniform Commercial Code and the Uniform Trust Receipts Act.

The mortgage category is more applicable to security interests because quite generally a mortgage is security for a debt. 33 Although the term mortgage connotes a security interest in real property, the commercial world recognizes the general rule that any kind of property which may be sold or conveyed may be mortgaged. ${ }^{34}$ Accounts receivable can be bought and sold; they can secure debts; therefore, they are an interest relatively similar to a realty

greater property rights than a lienor's claim. " $A$ lien is distinguished from an assignment in that it is a charge upon property, while an assignment creates an interest in property." First State Bank v. United States, 166 F. Supp. 204, 207 (D. Minn. 1958). Accord, Springer v. J. R. Clark Co., 138 F.2d 722, 726 (8th Cir. 1943). There is significance in that distinction. "In the one case the property can be conveyed subject to the lien; or even free of the lien. In the other case, the portion assigned can be conveyed only by the assignee who is a coowner with the assignor." Millsap y. Sparks, 21 Ariz. 317, 320, 188 Pac. 135, 136 (1920). Accord, Nichols v. Orr, 63 Colo. 333, 166 Pac. 561 (1917). The conclusion here is that assignments as security interests convey a stronger property interest than do lien claims against property, even though the assignments may be considered liens themselves. They are the caliber of interest set apart by section 6323 .

31 United States v. Chapman, 281 F.2d 862 (10th Cir. 1960).

32 See Steelcraft Mfg. Co. v. Hewkin, 148 F. Supp. 872, 876 (E.D. I1l. 1956): “The bank does have priority over the tax claim of the government. ... The assignment to the bank was executed long before the government's taxes were assessed. By virtue of 26 U.S.C.A. $\$ 6323$ ... the bank is a purchaser to the extent of the amount it advanced to Hewkin as present consideration for the assignment."

33 United States v. Gargill, 218 F.2d 556, 560 (1st Cir. 1955): ("One of the principal and necessary characteristics of a mortgage is the fact that it is security transaction."); McGowan v. Williams, 241 Ala. 588, 590, 4 So. 2d 164, 165 (1941); McGough v. Sweetser, 97 Ala. 361, 364, 12 So. 162, 163 (1893) ("A mortgage in equity and in fact is only a security for the payment of a debt."); Stenfield v. State, 37 Ariz. 389, 392, 294 Pac. 834, 835 (1930) ("II]t [mortgage] is nothing but a lien for the security of money or some other conditions .....").

34 Elmonte Inv. Co. v. Shafer Bros. Logging Co., 192 Wash. 1, 24, 72 P.2d 311, 321 (1937); Bonded Bldg. \& Loan Ass'n v. Konner, 113 N.J. Eq. 99, 166 Atl. 79 (1933): "A mortgage operates upon whatever interest the mortgagor had and anything the subject of contract or assignment may be mortgaged." Curtis v. Root, 20 Ill. 518, 522 (1858): "The doctrine is understood to be that every thing which may be considered as property, whether in the technical language of the law denominated real or personal property, may be the subject of mortage ...." See 59 C.J.S. Mortgages $\$ 71$ (1949). 
lien and, as such, are capable of inclusion within the legal concept of mortgage. This would be especially true if the courts were to adopt the broad definition of "mortgage" contained in the Internal Revenue Regulations. ${ }^{35}$ Support for a broad definition is found in an old Supreme Court decision which held that an assignment of goods on board a ship as collateral for a loan "was . . . a mortgage of the goods. ..."36 In that case the assignee insurance company was given priotity over a government debt and in so doing the Court treated the security interest assignment as a mortgage. The practice of equating an assignment of property as security for a debt with a mortgage of property has been followed in subsequent cases. ${ }^{37}$ An absence of title to the assigned account is of little significance because of a general desire to avoid notions of title in favor of the underlying realities, and in view of the fact that many real estate mortgagees similarly lack title to their security interest. The breadth of meaning behind the statute's "any mortgage" was further demonstrated by a case finding that a contract lienor "in the position of one holding a mortgage came within the statute" $: 38$ The equivalence of assignment and mortgage was reaffirmed in 1960 when surety assignments of crude oil proceeds were held to be a mortgage and therefore superior to after-recorded tax liens. ${ }^{39}$ It can thus be concluded that a security interest in accounts receivable may easily fall within the mortgage term of the statute. Thus it was by no means unwarranted for the lower court decision in Ball to consider the creditor company's assignment as being a mortgage in the usual commercial sense and consequently within the statute. 40 Nevertheless, the law announced by the Supreme Court's decision in Ball and followed in subsequent lower court cases denies mortgagee status to accounts receivable assignees. This exclusion, however, is not founded on a definitional basis because as one case points out the assignment interest is still a mortgage in a sense; 41 rather it is a failure to meet

35 See text accompanying note 25 supra.

36 Conrad v. Atlantic Ins. Co., 26 U.S. (1 Peters) 386, 446 (1828). See Brief for Respondent pp. 15-17, United States v. R. F. Ball Constr. Co., 355 U.S. 587 (1958); Note, 43 MiNN. L. REv. 755, 769 n.105 (1959): "Furthermore, since the Court has never expressly or impliedly reversed the Conrad decision, it must be assumed that the Court's early interpretation of an assignment of a chose in action as a mortgage is still law."

37 Mallers v. Equitable Life Assur. Socy, 87 F.2d 233 (7th Cir. 1936); Yenni v. McNamee, 45 N.Y. 614 (1871). See 6 C.J.S. Assignments § 2(8) (1937).

38 Evans v. Stewart, 245 Ia. 1268, 66 N.W.2d 442 (1954).

39 Elliott v. Sioux Oil Co., 191 F. Supp. 847 (D. Wyo. 1960).

40 R. F. Ball Constr. Co. v. Jacobs, 140 F. Supp. 60,65 (W.D. Tex. 1956. That is, the indemnity mortgage as a commercial transaction was clearly a mortgage-type interest and section 6323 did not require that such mortgage be "due at a certain time and in a certain amount and ... duly recorded in accordance with law"; "the law of Texas, where the questioned assignment was made and was to be performed, makes such an 'assignment' a valid mortgage." United States v. Ball Constr. Co., 355 U.S. 587, 593 (1958) (dissent).

41 First State Bank v. United States, 166 F. Supp. 204, 208 (D. Minn. 1958). 
choate lien standards that prevent inclusion under the terms of section 6323.42

Shifting to the major consideration of choateness, one is faced with the first of several formidable problems-in the proper interpretation of the Ball opinion. At least three different meanings have been attributed to the brief but ambiguous holding:43 "The instrument involved being inchoate and unperfected, the provisions of $\S 6323$ do not apply." A 1960 dissenting opinion in a Fourth Circuit case argued that the Court in Ball considered the assignment as not tantamount to a mortgage because otherwise it would have elaborated on its reasoning for this initial invocation of the choate lien rule into the section 6323 area.44 The argument is supported with the observation that the only two cases cited in the per curiam concerned statutory liens under the basic tax lien statute rather than section 6323 interests. 45 However, the distinct reference to section 6323 in the per curiam tends to weaken this argument significantly.

A middle position argues that the surety's failure to record his assignment or to take other steps for the protection of his security interest was looked on by the Court as a failure to perfect in the commercial sense. 46 This interpretation of the use of "inchoate and unperfected" is more desirable than probable. However, the majority of subsequent cases have accepted a third position which regards the holding of Ball as an ultimate extension of the general "inchoate lien" theory to section 6323 security interests. 47 This extension finds little support in the legislative history of section 6323 . The statute was occasioned in part by a Supreme Court holding that a federal tax lien was valid and binding even against a bona fide purchaser or encumbrancer in good faitl

42 An assignment of accounts receivable may also be designated as a pledge, provided that the assignee has possession of something which sufficiently represents the accounts or the right to receive them.

A pledge is a lien created by the delivery of personalty by the owner to another upon an express or implied agreement that it shall be retained as security for an existing or future debt, and to create a pledge the pledgee must have possession and control of the property. Immel v. Travelers Ins. Co., 373 Ill. 256, 26 N.E.2d 114 (1940).

43 "The scope and extent of the decision of the United States Supreme Court in that case [Ball] is not clear." Randall v. Colby, 190 F. Supp. 319, 339 (N.D. Iowa 1961).

44 United States v. Bond, 279 F.2d 837 (4th Cir. 1960). See 13 Stan. L. Rev. 389, 393 n.24 (1961).

45 United States v. City of New Britain, 347 U.S. 81 (1954); United States v. Security Trust \& Sav. Bank, 340 U.S. 47 (1950).

46 Note, 43 MINN. L. REv. 755, 781 (1959). Although the mortgage was valid under Texas law, the author suggests that commercial perfection required something more. Specifically, the alternatives to enforce sufficiently one's lien against subsequent creditors would be either to record the security interest or to take possession of the secured property.

47 United States v. Crest Fin. Co., 291 F.2d 1 (7th Cir.), cert. granted vacated and remanded, 368 U.S. 349 (1961), opinion on remand, (7th. Cir. May 3, 1962); Arthur Co. v. Chicago Paints, Inc., 175 F. Supp. 50 (D. Minn. 1959); First State Bank v. United States, 166 F. Supp. 204 (D. Minn. 1958). See United States v. Bond, 279 F.2d 837, 845 (4th Cir. 1960); Elliott v. Sioux Oil Co., 191 F. Supp. 847, 850 (D. Wyo. 1960): "Under the rule ... pronounced in ... Ball the lien must be perfected in order to be privileged by $\$ 6323 . "$ 
for value, without knowledge or notice of the existence of such a lien. 48 Ostensibly the recording requirement was aimed to protect those persons who might seek interests in property to which a government tax lien had already attached. The inchoate lien rule was at that time unpromulgated and one assumed that valid security interests acquired prior to an attaching tax lien had priority under the old equity rule which insured priorities in accordance with time. The very fact of the statute's enactment and its continued existence indicates legislative recognition of the value and importance of protecting and maintaining the rights associated with the enumerated property interests. This view is substantiated by the history of the bill in committee. A judicial committee's report on the proposed bill stressed that it was

[I]mperative that some legislation of this kind be enacted in order to protect the transfer of property, and to facilitate business transactions. There is no reason why the government should not occupy the same position with reference to liens on property as does the individual.49

Although there seems to be "no reason why" the government should occupy a better priority position than temporally identical individual lienors, the application of the perfected lien doctrine has achieved precisely this result.

An examination of the legislative history of section 6323 suggests the conclusion that Congress did not intend to establish priorities over competing lienors through the statute's enactment. Rather, the current preferential priority status of the federal tax lien in relation to section 6323 interests has been established by judicial legislation. A possible rationale for this result has been expressed in Bankhead v. Maryland Cas. Co., where the court stated that "assignments . . . although prior in time ... are subordinate ... because of the greater dignity of the tax lien . . ." 50 A conclusionary rationale of this type,

48 United States v. Snyder, 149 U.S. 210 (1893). See H.R. REP. No. 1018, 62d Cong., 2d Sess. (1912), Judiciary Committee's Report submitted by Mr. Sterling. "In the case of the United States v. Snyder (149 U.S. 210) the Supreme Court held that the lien created by $\S 3186$ (currently $\S 3621$ ) is a valid binding lien even against a bona fide purchaser or encumbrancer in good faith for value, without knowledge or notice of the existence of such a lien.... [A]ny person taking title to real estate is subjected to the impossible task of ascertaining whether any person, who has at any time owned the real estate in question, has been delinquent in the payment of the taxes referred to while the owner of the real estate in. question."

49 H.R. REP. No. 1018, 62d Cong., 2d Sess. (1912), Judiciary Committee's Report submitted by Mr. Sterling.

so Bankhead v. Maryland Cas. Co., 197 F. Supp. 879, 882 (E.D. La. 1961). In Ball, the subcontractor had assigned to a surety all funds due under a contract as security for the issuance of a performance bond and for possible future indebtedness to the surety. The government tax lien was then filed. There was no specific debt owing at the time, and the assignment lacked specificity of amount. In Bankhead, the obligation on a similar performance bond had materialized prior to the government assessment. In either case the surety's obligation was legally enforceable and under a "relation back" theory the subsequent debt incurred in the Ball situation would have temporal priority over the tax lien.

The relation back theory was found valid in the past but more recent decisions and a treasury regulation concerning advances on mortgages subsequent to the filing of a tax lien 
however, does not illuminate the reasons for affording greater protection to the federal tax lien.

It is one thing, and going far, to elevate the federal lien by cutting off inchoate interests. It is quite another, and going much further, to use the inchoate concept to cut off interests which Congress has expressly protected in language that makes no reference to the matter of inchoateness. 51

The major problem of Ball, however, is not its inconsistency with congressional intent, but rather the Court's failure to articulate the reasons for its decision. This has the effect of leaving the concept of perfection-choateness open to all manner of tests and standards. Overly pervasive criteria could defeat almost any type of mortgage security interest where the exact amount owing, and in the case of accounts receivable, the specific account, are not specified prior to a tax assessment. 52 Even if the security interest is specific in every possible way, it might be ruled inchoate if the assignee's basic right to the account is contingent on the assignor not paying off directly on the note. 53

have severely limited its effect. See Anderson, Federal Tax Liens-Their Nature and Priority, 41 CALIF. L. Rev. 241, 267-68 (1953). Rev. Rul. 144, 1956-1 Cum. Bull. 562, 563: "In the case of an 'open-end mortgage' which covers future advances, it is possible that no future advances may ever be made. Therefore, until such an advance is actually made, there can be no fixed and specific or perfected lien under Federal law as distinguished from a mere contingent lien or 'caveat of a more perfect lien to come.' Consequently, an intervening recorded Federal tax lien has priority over advances made subsequent to the date of such recording."

"Definitely contracted for obligatory advances made under a properly executed and recorded construction loan mortgage "were excepted from the open-end mortgage rule by an unpublished ruling A-61937-8/24/56." Wolson, Federal Tax Lien, 43 MARQ. L. REv. $180,192 \mathrm{n} .34$ (1959). This seems quite reasonable in that the mortgagee is contractually obligated to make future advances if the condition or contingency materializes; therefore, the absence of specificity of amount should not be detrimental to perfection. Otherwise the securing of contingent debts would provide little security when a potential tax defaulter is involved.

The type of indemnity mortgage used in Ball and Bankhead is not at all uncommon. Where sureties make performance bond contracts, the consideration assigned for their contingent obligation would seem entitled to protection against subsequent claims. It is especially significant in contractor cases where in the business by its very nature risks of failure are great and a failure to perform, thus obligating the surety, may often be accompanied, if not preceded, by a default on employees withholding taxes. See Wall Street Journal, Dec. 28, 1961, p. 1, col. 5: "Contractor bankruptcies take a thick slice out of profits of surety firms. Surety firms guarantee to the Government or other agencies that contractors will perform on time the specifications of contracts. ... In recent years increased competition in the construction industry has pushed many builders into profitless sledding. As a result, contractor failures in 1961 were about $16 \%$ of all business failures, according to Dun \& Bradstreet." In the face of such realities the bonding companies need sufficient protection for their security assignments against subsequent federal tax liens despite the contingency of their obligation.

51 Cross, Federal Tax Claims, 27 Fordham L. Rev. 29 (1958).

52 See the priority statute cases, supra note 12 , and the statutory lien cases under section 3621 , supra note 13. If the courts were to follow these earlier cases the same harsh tests and standards could be brought to bear against section 6323 interests.

53 Cf. First State Bank v. United States, 166 F. Supp. 204, 209 (D. Minn. 1958). But see Hoare v. United States, 294 F.2d 823 (9th Cir. 1961), which held that a chattel mortgage on 
Such an interpretation would defeat virtually all security devices. The completeness of choateness may also be interpreted to require a transfer of title and possession. ${ }^{54}$ Yet many mortgages, as mentioned above, satisfy neither of. these requirements. Unfortunately, these ruminations are more than speculations. Post-Ball decisions in the security field have dangerously expanded the magic words "inchoate and unperfected."

The Ball decision had just been handed down when a Minnesota district court in First State Bank v. United States 5 gave priority to a federal tax claim. over the prior assignment of an account receivable. The fund in dispute was contract payments that a defaulting taxpayer had previously assigned to the bank as security on several loans. The court awarded priority to the subsequent federal tax lien. "A majority of the court in the Ball case rejected the contention that an assignment as in the case at bar constitutes a mortgage within the meaning of $\S 6323$. This Court must hold likewise here." 56 The opinion is enlightening: "It is urged [that] the Bank is, in one sense a mortgagee. That may be true. This does not mean however that the Bank is a mortgagee as contemplated in the statute. The Supreme Court has imposed a 'perfected lien' standard upon lien interests that are recognized under this statute." 57

Thus the implications of Ball became express. Although Ball involved contingent indebtedness and the case before the district court involved ascertained indebtedness, the court refused to distinguish Ball on this basis. It stated that, "Admittedly this is a distinguishing characteristic, but the distinction does not perfect an unperfected lien." 58

The bank is recognized as a secured creditor whose assignment passed the specificity tests of identity and certainty and was even considered a mortgagee "in a sense"; yet the bank's lien remains unperfected as against a subsequent federal claim. The reason for this result is then presented:

The fact that the purported assignment here was given to secure a specified sum, and that the notes fell due on dates certain, relieved any lien which might arise of certain imperfections, but so far as the tax law is concerned,

fixtures given by tax debtors as security for their performances of a lease and filed prior to notice of a tax lien had priot ity over the federal tax lien. The court said: "Indeed the underlying promissory note may not yet be due and still section 6323(a) protection is available. This is true despite the fact that under either of these circumstances the mortgagor may, subsequent to the tax lien, pay the obligation if or when due and so avoid foreclosure." Id. at 827. It is difficult to find reasons for distinguishing between furniture and accounts receivable in the application of this statement.

54 Leipert v. R. C. Williams \& Co., 57-2 U.S. Tax Cas. 58, 626 (S.D.N.Y. 1957). There, persons who took possession of real estate under an installment purchase contract without receiving a deed were not regarded as "purchasers" under section 6323 and were not even protected with respect tc the payment made in good faith before the lien was filed. The court held that the lack of a deed was a failure to perfect; thus a subsequent tax lien was accorded priority.

s5 166 F. Supp. 204 (D. Minn. 1958).

57 Id. at 208.

56 Id. at 210.

58 Id. at 209. 
the lien itself remained unperfected, at least until some action was taken to enforce it. Furthermore, the matter of contingency is not limited solely to indefiniteness of time or amount. A lien interest, in and of itself, is indefinite. Contingency is the very basis of a lien-if an obligor fails upon a primary obligation, the lienhold interest, though already in existence becomes the basis of an enforcible right. The exact status of lienhold interests at any particular time always has been a difficult question. It is only proper therefore that the courts have erected the perfected standard to determine when the lien interest becomes cognizable in the federal tax lien law. 59

This statement comes close to saying that a security interest is by nature unperfectible. Certainly this is a possible implication from the court's language defining liens as basically contingent and indefinite and therefore presumably unperfected until enforcement. Apparently the court is saying that an assignee must have initiated judicial proceedings or other tangible action aimed at the ultimate transfer in order for his security interest to be perfected. The unanswered question is how far along this enforcement process must one go in order to be sure of having a perfected interest. It is not pure speculation for one to assume that "perfection" may require the lien to have become a definite possessory property interest. The unfairness is obvious. Even where the due date on the primary obligation has expired, as in the Medford Bank case, reasonableness in both time and motive should govern any obligation on the lienor to foreclose immediately. A creditor should be free to extend a debtor's due date, even implicitly by not seeking collection, without endangering his own security, unless the extension might operate as a fraud upon other creditors. This is by no means to suggest that enforcement could be neglected for any significant amount of time without good cause. A secured creditor is not immune from business risk.

A subsequent Minnesota case dealt with a more common type of accounts receivable financing. $60 \mathrm{~A}$ bank had been financing a paint company and periodically taking assignments of accounts receivable as security for an open line of credit. The paint company neglected its tax withholding responsibilities and the inevitable tax lien descended on a previously assigned account. The court found that "The Bank's claim is based on instruments which remained unperfected as a basis for priority. Thus it became subordinate to the tax liens." 61 Once again the Ball decision determined the conclusion of "inchoate and unperfected." The only elucidation of this conclusion is a footnote reference to a lack of recordation which is not required under Minnesota law. The Medford case is cited as construing Ball to have held that "an assignment [does not constitute] a mortgage within the meaning of the notice filing provision." 62 Having eliminated this category, the opinion rejects the bank's claim to be a "purchaser" within section 6323 on the basis of the restrictive vendor-

s9 Ibid.

60 Arthur Co. v. Chicago Paints, Inc., 175 F. Supp. 50 (D. Minn. 1959).

61 Id. at 53.

62 Ibid. 
vendee definition. ${ }^{63}$ Impliedly the bank lacked title to the accounts and therefore failed to fit the category.

Less than a year later a similar case came before the Court of Appeals for the Tenth Circuit. ${ }^{64} \mathrm{~A}$ contractor secured several loans by assigning to a finance company the proceeds of a construction contract with a telephone company. Subsequently, a tax lien was filed. Eventually the phone company interpleaded the retained proceeds which were insufficient to satisfy all claimants. Again the tax lien received priority. The finance company had asserted that it was a purchaser because under Oklahoma law a chose in action is assignable and a valid assignment passes title. The court stated:

that an assignment given as security for a debt gives the assignee only a qualified interest in the assigned chose, commensurate with the debt or liability secured although the assignment is absolute on its face. . . . It is reasonable to conclude... that the assignee does not receive a transfer of absolute title. ...65

Juxtaposed against the vendee-vendor definition of purchase, the assignment was looked on as a security transaction rather than a sale. This reasoning led to the conclusion that the finance company was not a purchaser within the meaning of section 6323. "Instead it is a lienor." Accordingly the court suggested an application of the "perfected lien standard imposed by the Supreme Court in cases involving [statutory] liens under state law . . . ."66 By considering the interest before them as a lien, rather than as a protected interest under section 6323, the court avoided interpreting Ball as extending the choate lien doctrine to section 6323 interests. There is only one sentence in the opinion that even remotely hinted at what Ball has done in terms of the interests heretofore shielded by section 6323 .

The significance of the difference between contractual and statutory liens and the problems inherent in the imposition of the perfected lien principle on financial arrangements of the type here involved must have been considered by the majority in the Ball Construction Company case.... We are bound by that decision. ${ }^{67}$

In contrast, note the forthrightness of the Medford opinion. "This does not mean, however, that the Bank is a mortgagee as contemplated in the statute (\$ 6323). The Supreme Court has imposed a 'perfected lien' standard upon lien interests that are recognized under the statute." 68

An unresolved question is why the Court of Appeals took such pains to avoid the impression of applying the "perfected lien" theory to section 6323 while citing and discussing the three cases that did. Such reluctance may well indicate a restrained disapproval of the expansion; or it could merely be an expression of doubt and confusion as to what Ball actually meant.

63 See text accompanying note 28 supra.

64 United States v. Chapman, 281 F.2d 862 (10th Cir. 1960).
65 Id. at 868.
66 Id. at 869.
67 Id. at 870 .

${ }^{68}$ First State Bank v. United States, 166 F. Supp. 204, 208 (D. Minn. 1958). 
All three of these post-Ball decisions have rested on two basic findings: (1) the assignment is not perfected. (2) The assignee is not a mortgagee or purchaser within the terms of the statute. The manner of connection is what is significant. Does the second depend upon the first; is the relationship causal or independent? The wording of the different courts makes this question difficult to answer. But the results in the cases were the same. Taxes, coming second, take first.

The plight of Crest Finance Co.69 is the culminating illustration of the earlier problems faced by the assignee of accounts receivable. Crest made loans to a subcontractor who secured them with promissory notes and specific accounts receivable due or to become due from the general contractor. Subsequently, notice of a federal tax lien was filed against the subcontractor for failure to pay the withholding taxes of his employees. Citing Ball as controlling, the Court of Appeals for the Seventh Circuit found: "It is not necessary for us to decide whether the assignments here under examination were pledges under section 6323(a)... . [W] are required under United States Supreme Court decisions to hold that Crest's liens were not perfected, or, in the language of the Court, 'choate." "70

Crest leaves no doubt that the perfected lien theory is equally applicable to section 6323 interests. Therefore, classification under a statutory term is irrelevant and perfection alone is the requirement to be argued. This would seem to be the law. To many, it is confused and harsh.71

The story of Crest, however, is not complete. While awaiting decision on petition for certiorari to the Supreme Court, the government announced an admission of error in October of 1961. The admission was that the Seventh Circuit had erroneously accepted Ball as controlling because actually Crest's liens were choate in regard to specificity. "The requirement of definiteness of amount goes only to the debt secured by the lien, not to the property (otherwise specifically identified) that is subject to the lien."72 Therefore a liquidated

69 United States v. Crest Fin. Co., 291 F.2d 1 (7th Cir.), cert. granted vacated and remanded, 368 U.S. 349 (1961), opinion on remand 000 F.2d 000 (7th Cir. 1962).

$70 \mathrm{Id}$. at 3.

71 "The federal lien priority "has many evil facets, but most of them share a single characteristic.' The government collects its revenue and other claims to an increasing extent, not from its taxpayers . . . but from those who enter into business relations with taxpayers. . . . The increased risks of extending credit operate to make credit obtainable only upon more onerous terms." MacLachlan, Improving the Law of Federal Liens \& Priorities, 1 Boston COLLEGE IND. \& COMM. L. REv. 73, 75 (1959). This reasoning is further outlined in In re Halprin, 280 F.2d 407, 410 (3d Cir. 1960): "Such a lender ... has enriched the taxpayer's estate by the amount loaned to the taxpayer. For this reason, it is not unreasonable to allow it a corresponding security interest in the fruit of the borrowed money with the government relegated to the borrowing taxpayer's net after the lender is reimbursed. The government has suffered no diminution of the assets which were available to satisfy its tax claim hefore the loan."

72 Memorandum of Respondent in Opposition to Certiorari, p. 6, Crest Fin. Co. v. United States, 291 F.2d 1 (7th Cir.), cert. granted vacated and remanded, 368 U.S. 349 (1961), opinion on remand, (7th Cir. May 3, 1962). 
value of the accounts owed was not essential to the choateness of the assignee's interest. The logic is sound. As a limitation on the scope of the choate lien doctrine, the admission is desirable, but of questionable impact. The requirement of specificity of amount, although brought closer to reasonable commercial standards, is only one of several prerequisites to perfection which tend to threaten the stability of secured credit. Although admitting perfection in regard to specificity, the United States attorney nevertheless contended that Crest's failure to record its assignment rendered it unperfected. It was on this question that the government sought a rehearing in the lower court. The rehearing was obtained on a remand from the Supreme Court whose per curiam had accepted the government contention that Crest's lien was choate. However, the Seventh Circuit held against the government on the recording issue. An Illinois statute validates unfiled assignments of accounts receivable and the court would not accept the government's distinction between absolute and security interest assignments. ${ }^{73}$

The government's emphasis on recordation does not seem unwarranted. Protection of third parties by outward and visible signs of a debtor's true financial position seems to be the fundamental notion underlying the concept of perfection. Although there are a variety of other devices, the basic method of giving notice is recordation. Indeed, every aspect of specificity and perfection is related to this policy of publicizing transactions so that subsequent creditors and purchasers are appraised of what has gone before. Although it might be assumed that such notions are inherent in the thinking of courts applying the choateness rule, curiously the cases say almost nothing about a notice policy as justification for the stringency of perfection. Even early decisions merely mention the lienor's failure to seize or specify, without articulating the necessity or desirability of these acts in terms of notice. 74

A failure to record would seem to defeat the notice policy behind perfection. Suggested as an additional imperfection in both Minnesota cases, 75 the absence of recordation should perhaps be regarded as an unexpressed justification for the decisions discussed above. Although unrecorded assignments are considered valid and perfected under Illinois and Minnesota statutes, the priority of claims is a federal question, and the notion of the federal courts seems to be that the secunity interest should be publicly filed for federal perectibility. However, when the relevant parties are limited to one lienor-as-

73 United States v. Crest Fin. Co., No. 13226, 7th Cir., May 3, 1962.

74 One reason may lie in the nature of the government's lien itself. With the exception of section 6323 interests, no notice of the federal tax claim is required. Other aspects of perfectibility such as enforcement measures and specificity of the attached property are also noticeably absent from the ordinary government tax lien. Such blatant inconsistency was challenged in the past, but an assumption of automatic perfection now arises upon the introduction of a tax lien. See Anderson, supra note 50 at 243-45 for cases and analysis.

75 Arthur Co. v. Chicago Paints, Inc., 175 F. Supp. 50, 53 n.7 (D. Minn. 1959); First State Bank v. United States, 166 F. Supp. 204, 210 (D. Minn. 1958). 
signee and one government, the argument becomes tenuous. As already observed, the fundamental reason for recording is to give notice of prior encumbrances to persons seeking interests in property. In connection with this policy, the phrases "secret lien" and "the government had no notice of the Bank's alleged lien" appearing in the Medford opinion should be noticed.76 Then it must be asked what possible good it could do the government to have notice of the Bank's lien. The whole function and purpose of publicity is inapplicable when the government is involved. Obviously taxes will not be postponed because notice of a prior encumbrance is received. One argument to the contrary might be that none of the perfection prerequisites necessarily benefit the government, aside from promoting efficient and orderly administration of commercial affairs. A sincere desire to encourage recording as a protection device for the general commercial community might justify superseding state validity laws.77

This argument, however, raises a serious problem of federalism. If unrecorded interests are commercially perfected in the state in which the business is conducted and there are no positive benefits to be derived by the federal tax claimant from making recordation a prerequisite to choateness, then there appears little reason to subordinate an assignee who is in full compliance with local law to a subsequent federal tax lien. Recordation of accounts receivable assignments is required in only a bare majority of the states. ${ }^{78}$ It seems unfair to prejudice the interests of those who live in states where devices other than recording suffice for validation and perfection of assignments. How can a man be expected to record interests for which there is no established procedure or device within the state? One cannot deny the universal abhorrence of secret liens, but it is difficult to believe that any state has left this problem unconsidered. Therefore, it seems that federal priorities law based on the choate lien doctrine unreasonably disregards state commercial legislation if, as it may be interpreted, failure to record means "inchoate and unperfected." Uniform recordation requirements, no matter how desirable or necessary for the assignments of accounts receivable, should be put into effect only by legislative action. 79

The import of the post-Ball cases can be simply summarized. There were four decisions obviating valid security interests, all significantly "more perfected" than the Ball mortgage, on the basis of a legal formula which was introduced without definition or limits. All of the asignments secured present and existing debts; they were perfected commercial interests for the purpose of

76 First State Bank v. United States, 166 F. Supp. 204, 210 (D. Minn. 1958).

77 Nor should one forget that mortgages generally, under which label assignments of accounts receivable have been placed, require recordation under state law.

78 See Comment 28 U. CHI. L. Rev. 130, 135 (1960). tainty.

79 Otherwise lack of uniformity might be compounded with an additional lack of cer- 
state law; yet in each instance a subsequent federal tax lien was accorded priority over the secured creditor's interest.

It is clear that Ball and its progeny may have important commercial consequences. The creditor who usually asks for security on his loan is likely to be doing business with smaller companies whose financial positions are not very stable. 80 Companies of this type need lenders and the lenders in turn need security because of the relatively high possibility of default. A failure to pay on the primary obligation will probably be accompanied by a failure to pay other debts including taxes; therefore one sees little value in bargaining for security if at the time when the security claim would be pressed a federal tax lien is also likely to be present and apparently superior. Such a lessening of the value of security might lead to a rise in the price of credit with consequent effects on investment and growth.

The specific consequences of the case law for assignees of accounts receivable are not especially clear. It appears that it will be quite difficult for assignees of accounts receivable to comply with the standards for perfection expressed and implied by the Ball line of cases. The stringency of specificity of amount and enforcement requirements might render unenforceable prior liens of even the most conscientious creditors. The American Bar Association has recognized this problem and sponsored a bill to effect sweeping reform of the federal tax lien situation. This comprehensive legislation would give priority to all prior security assignments which are made effective under state law. The proposed bill has never been reported out of committee, although it was introduced in the Eighty-sixth Congress and reintroduced in 1961.81

Perhaps the best argument against the choate lien theory lies in analogy to the priority position of tax liens where the taxpayer is bankrupt. "Under the Bankruptcy Act, a lien is subject to the first in time, first in right principle with respect to competing liens. Thus, if a contractual lien is perfected before the government perfects its tax lien, the former is given priority." 82 In the bankruptcy situation Congress has had a chance to delineate a concept of perfection while establishing a prionity system. In defining the validity of the bankrupt's transfers to lien creditors, aside from fraudulent preference considerations, Congress has consistently adopted standards based on state perfection requisites. ${ }^{83}$ That is, a creditor's security interest valid against subse-

80 See MacLachlan, Current Developments Relating to Federal Liens and Priorities, 66 Coм. L. J. 265 (1961).

81 See Moore, Development in Accounts Receivable Financing, 16 Bus. LAw. 818, 822 n.4 (1961); Plumb, Federal Tax Liens, 47 A.B.A.J. 455 (1961); Plumb, Effect on Banks and Secured Lenders of Federal Tax Lien Proposals, 14 Bus. LAW. 782 (1959); A.B.A. REPORT OF the Committee on Federal Liens, Draft of Proposed Legislation \$ 6323 at 65-66, (1959).

82 Note, Applicability of the "General and Unperfected Lien" Doctrine to Contractual Liens, 43 MinN. L.. RFv. 755, 775 (1959).

83 See Porter v. Searle, 288 F.2d 748 (10th Cir. 1955) (perfection of an equitable lien under Utah law); B. F. Avery \& Sons Co. v. Davis, 226 F.2d 942 (5th Cir. 1955); M. M. Landy, Inc. v. Nicholos, 221 F.2d 923 (5th Cir. 1955) (an assignment perfected under local 
quent lienor-creditors under prevailing state law was considered a valid transfer for the purposes of the Bankruptcy Act, 84 and thus achieved priority over unsecured creditors' claims. According to the priority rankings, United States tax claims stand fourth on a five-rung ladder, in perfect equality with state tax claims. ${ }^{35}$ Thus, if bankruptcy preceded the attaching federal tax lien, Crest's assignment, being superior to subsequent lienor creditors under the Illinois validity law despite lack of recordation, would enjoy priority over the Government interest. The discrepancy in treatment of secured creditors by Congress and the courts seems illogical and unrealistic. Although the recent amendment to the Bankruptcy Act has been criticized for its lack of uniformity, ${ }^{86}$ its test of a valid transfer, whether the security interest is sufficiently perfected under state law as against any subsequent lienor-creditor, insured more fairness and stability than did courts dealing with tax debtors who were close to bankruptcy.

This comment is not a recommendation for any and all assignments of accounts receivable to receive preference over subsequent federal tax liens. The rules of fraudulent conveyances must be kept in mind. Assignments made for old value should be watched and regulated at least as carefully as under the Bankruptcy laws. ${ }^{87}$ Specificity of the parties, the amount, and the property subject to the lien should exist to a certain degree. However, the degree should be limited by a basic commercial reasonableness. The fact that the amount of the security lien is uncertain to the extent of unliquidated interest payments or contingent charges should not deny choateness unless they are proportionally substantial. Recordation is a desirable fundamental for perfectability. If the assignee and assignor of accounts receivable have their names on file in relation to accounts reasonably identifiable under the commercial circumstances, then potential subsequent assignees, mortgagees, purchasers, and creditors in general can easily ascertain the more detailed specifics by referring to the named parties. Such recording would constitute sufficient notice to make the recording party's interest perfected as against subsequent private parties, and

law held good against trustee despite failure to comply with Federal Assignment of Claims Act). See also Com Exch. Bank v. Klauder, 318 U.S. 434 (1934); Matter of Cox, 132 F.2d 881 (7th Cir. 1943); Matter of Quaker City Sheet Metal Co., 129 F.2d 894 (3d Cir. 1942); COLLIER, BANKRUPTCY $\S 60.39$ at 913 (14th ed. 1941). "It is evident that, under $\S 60 \mathrm{a}$, the determination of when a transfer is perfected depends almost wholly on state law." Comment, 28 U. CHI. L. REv. 130 (1960).

8464 Stat. 24 (1950), 11 U.S.C. $\$ 60$ (a) (1958). A security interest is deemed perfected when "no subsequent lien upon such property obtainable by legal or equitable proceedings on a simple contract could become superior to the rights of the transferee."

8511 U.S.C. $\S 104$ (a)(4) (1958).

${ }^{86}$ See Comment, 28 U. CHr. L. REv. 130 (1960).

8711 U.S.C. $\$ 107$ (a) (1958): The trustee is given power to avoid any transfers for antecedent debts made within four months of bankruptcy if there is reasonable cause to believe such transfer was a preference. 
this standard should be respected by the federal tax collector. This system would allow the continuation of a going financing, a distinct commercial situation from that faced by the court in Ball, while providing all necessary protections to future third parties.

The question of dominion 88 over specific accounts raises a balancing problem between protecting the government from fraud and respecting accepted business practices. The inference of fraud from a debtor's dominion over the security interest has been deemed stronger where that interest is accounts receivable as opposed to real estate. Certainly the payment of assigned accounts into an assignor's collateral bank account, where the bank is the assignee, as Arthur Co. v. Chicago Paints, Inc., ${ }^{89}$ would seem to give the secured creditor reasonable control over his security. Notification to the obligor by the nonbank creditor of the presence of the creditor's security interest should also be sufficient.

Neither title nor possession should be prerequisites to a perfected security interest in specific property. The states, in their legal requirements for making mortgages and assignments valid, have recognized that the rights or property interests contracted for in a security dealing do not necessarily imply transfer of either title or possession. Certainly if perfection under the Bankruptcy Act depends on the individual state's requisites whether they be a written agreement, filing, notice to the account debtor, or none of these, there is no reasonable or logical reason why federal tax liens should require a different, more difficult, standard of perfection from its competitors when dealing with identical interests.

For the purpose of adjudging priority, the reasonable commercial standards that are applied to private lienors should also be applied to the government. Unless one assumes that government tax claims should receive priority because they are government tax claims, the overly expansive choate lien doctrine should contract to normalcy. Otherwise the practice of robbing Peter to pay Paul's taxes will continue to be sustained by the courts. $90 \mathrm{Mr}$. Justice Holmes once commented: "Taxes are the price we pay for a civilized society." 91 In the words of a 1961 commentator, "to undermine most securities by stigmatizing them as inchoate during most of the time they are needed, is an attempt to reverse the course of commercial civilization. ..."92

\footnotetext{
88 See Benedict v. Ratner, 268 U.S. 353 (1925). The doctrine of this case imputes fraud of creditors to transactions in which the assignor retained full dominion over the proceeds of accounts received. Such a lien was therefore void against creditors.

89175 F. Supp. 50 (D. Minn. 1959).

90 Plumb, Federal Tax Collection and Lien Problems, 13 TAX L. Rev. 459 (1958).

91 Compania General De Tobacos de Filipinos v. Collector of Internal Revenue, 275 U.S. 87, 100 (1927) (dissent).

92 MacLachlan, supra note 79 at 268.
} 